\title{
The Impact of the 2009 Special Supplemental Nutrition Program for Women, Infants, \& Children Food Package Revisions on Participants: A Systematic Review
}

\section{Authors: Danial Joseph Schultz, Carmen Byker Shanks, \& Bailey Houghtaling}

This is a postprint of an article that originally appeared in Journal of the Academy of Nutrition \& Dietetics on November 2015.

Schultz, Daniel Joseph, Carmen Byker Shanks, and Bailey Houghtaling. "The Impact of the 2009 Special Supplemental Nutrition Program for Women, Infants, \& Children Food Package Revisions on Participants: A Systematic Review." Journal of the Academy of Nutrition \& Dietetics 115, no. 11 (November 2015): 1832-1846. DOI\#: 10.1016/j.jand.2015.06.381 


\title{
The Impact of the 2009 Special Supplemental Nutrition Program for Women, Infants, and Children Food Package Revisions on Participants: A Systematic Review
}

\author{
Daniel Joseph Schultz, MS; Carmen Byker Shanks, PhD; Bailey Houghtaling
}

\begin{abstract}
For the first time since 1980, the US Department of Agriculture Food and Nutrition Service Special Supplemental Nutrition Program for Women, Infants, and Children (WIC) food package policies were revised in 2009 to meet the Institute of Medicine's nutrition recommendations. These changes included increases in fruits, vegetables, whole grains, and low-fat dairy to improve nutrition and health of WIC participants. Our systematic review of the literature assessed the influence that the 2009 WIC food package revisions have had on dietary intake, healthy food and beverage availability, and breastfeeding participation. The systematic review followed Preferred Reporting Items for Systematic Reviews and Meta-Analyses recommendations. Four electronic databases were searched between April 1 and 30, 2014, for peer-reviewed research. Two reviewers screened the articles, extracted the data, and established inter-rater reliability by discussing and resolving discrepancies. Twenty articles were included that met our inclusion criteria. Nine of the studies analyzed changes in dietary intake, eight exam-ined changes in healthy food and beverage availability, and three evaluated breast-feeding participation exclusively. The review demonstrated an improved dietary intake and an increase in the availability of healthier foods and beverages in authorized WIC stores. The revised food package was also associated with improved dietary intake of WIC participants. Mixed results were demonstrated in regard to improved breastfeeding outcomes. Further research is needed to assess the influence of WIC 2009 food package revisions on breastfeeding outcomes and to make conclusions about broad nutrition-related implications.
\end{abstract}

The missionof the United States Department of Agriculture (USDA) Food and Nutrition Service Special Supplemental Nutrition Program for Women, Infants, and Children (WIC) is to safeguard the health of lowincome women, infants, and children up to age 5 years who are at risk for poor nutrition.1 WIC, which was created as a 2-year pilot program in 1972 and made permanent in 1975, addressed the public and medical concern about malnutri-tion among low-income mothers and children.1 WIC provides nutritious foods to supplement diets, nutrition education, and referrals to health care and other social services. 1 The majority of WIC participants acquire foods through retail food stores (also called vendors) authorized by WIC state agencies. Authorized vendors carry WIC-approved foods and accept WIC checks, vouchers, and/or electronic benefit transfer.1 The focus of WIC has transitioned from preventing malnourishment to concerns of childhood obesity and exces-sive energy consumption combined with a low intake of fruits, vegetables, and whole grains have become the primary dietary concern of WIC participants.
The USDA Food and Nutrition Service charged a 2004 Insti-tute of Medicine (IOM) committee with reviewing the pro-gram's current supplemental food packages and evaluating the necessity of redesigning them to improve WIC participants' diets in regard to nutrition-related diseases. ${ }^{2}$ The IOM devel-oped a report from their findings entitled, WIC Food Packages: Time For Change, ${ }^{2}$ which recommended WIC match the current dietary guidance for infants and young children. The commit-tee's revisions encouraged consumption of fruits and vegetables $(\mathrm{F} / \mathrm{V})$, emphasized whole grains, lower saturated fat, and food packages that appealed to diverse populations. ${ }^{2}$ Informed by the IOM recommendations, the USDA published an interim rule for the food packages on December 6, 2007, that required all revisions to be implemented by October 1 , 2009. ${ }^{3}$ The interim rule largely reflected the IOM recommendations. 4 However, due to certain cost containment modifications, the interim ruling did not provide all WIC participants with a $\$ 10$ cash voucher allotment for $\mathrm{F} / \mathrm{V}$ purchases as recommended by the IOM. Exclusively breastfeeding mothers were provided with a $\$ 10$ per month $\mathrm{F} / \mathrm{V}$ cash value voucher and all other 
women received an $\$ 8 \mathrm{~F} / \mathrm{V}$ cash value voucher. This decrease in allotment for $\mathrm{F} / \mathrm{V}$ cash value vouchers was later changed to provide all WIC participants with the IOM \$10 recommendation. ${ }^{4}$

The final ruling on March 4, 2014, expanded whole-grain options, provided yogurt as a partial substitute, allowed parents to buy fresh F/V instead of jarred baby food, and gave states the flexibility to meet the needs and cultural preferences of their WIC participants. ${ }^{5}$ The final ruling still included the revisions of more fruits, vegetables, whole grains, a reduction in juice consumption, and a switch from whole milk to low-fat milk for children aged 2 years and younger. ${ }^{5}$ The revisions also incentivized and supported breastfeeding by increasing the amount of food allotted and the length of time the exclusive breastfeeding package could be provided. In contrast, the amount of formula for women partially breastfeeding was decreased to incentivize the exclusive breastfeeding package. ${ }^{5}$ The 49,000 WIC-authorized retail stores were required to stock specific items such as fruits, vegetables, and whole-grain products to benefit from sales related to WIC. ${ }^{5}$ Overall, these revisions aimed to improve dietary intake, increase breastfeeding participation rates, and expand healthy food and beverage availability at retail stores.

Although evidence exists about dietary intake, healthy food and beverage availability, and breastfeeding participation of the 2009 WIC food package revisions, to our knowledge, no systematic review exists that assesses the overall influence of the 2009 WIC food package revisions. Therefore, the objective of this review was to assess the effects of the 2009 food package revisions on healthy food and beverage availability, breastfeeding outcomes, and dietary intake of WIC program participants 5 years later using only peer-reviewed research.

\section{METHODS}

Articles included in this review were extracted from CINAHL, Cochrane Database, Web of Knowledge, and PubMed through a systematic review of literature utilizing the Preferred Reporting Items for Systematic Reviews and Meta-Analyses format. ${ }^{6}$ The authors tested potential key words related to WIC packages and revisions found in the Medical Subject Headings Library (http://www.nlm.nih.gov/mesh/) through mock searches to ensure that the final list of terms captured relevant articles that met inclusion and exclusion criteria. Final terms used in this search included a combination of the following words: WIC; The Special Supplemental Nutrition Program for Women, Infants, and Children; food package; and 2009 revisions. Reference lists of primary studies were scanned for additional citations. Inclusion criteria for manuscripts were peer-reviewed, English language, and United States. Meeting abstracts were excluded due to limited information provided. Articles were added to the initial review in cases where the title, abstract, or key words indicated that the study analyzed the implications of the 2009 WIC food package revisions, measured availability of healthy food and beverages at WIC retail locations, breastfeeding participation, and dietary intake, and were published before the peerreviewed study was started April 1, 2014, and ended April 30, 2014. Articles were excluded if published before the 2009 WIC revisions occurred, did not analyze changes due to 2009 WIC revisions, or focused on other federal food and nutrition assistance programs.
Two coders (D. J. S. and C. B. S.) independently extracted and then compared data to resolve any discrepancies through consensus. Both coders extracted information into a standardized form from selected articles and eligibility criteria into a table to note author, year published, research design, participants, location, data collection, study description, and results (see Table 1). Risk of bias was noted by assessing publication and funding mechanisms, experimental design (eg, whether there was a control group), sample size, followup measures, validity and reliability of the data collection instrument, and reporting. Where quantitative results existed, no summary measures were addressed due to inconsistent measurement methods across studies.

In total, 28 articles were identified in the initial review. Full articles were read for inclusion in the study. Two articles were excluded because they did not assess the 2009 WIC revisions and six articles were excluded because they were conference abstracts (see the Figure). This study was exempt from institutional review board review because there was no interaction with human subjects.

\section{RESULTS}

Twenty articles met the aforementioned study criteria (see the Figure). The following sections summarize changes in dietary intake, availability of healthy foods and beverages, and breastfeeding outcomes. Eight of the studies examined changes in the availability of healthy foods and beverages, nine analyzed changes in dietary intake, and three evaluated an increase in breastfeeding participation. The articles reported a variety of quantitative and qualitative research methods, including cross-sectional surveys, secondary data analysis, inventories, and interview methodology.

\section{Dietary Intake}

Dietary changes after the 2009 WIC food package revisions were observed among WIC participants across several food groups. ${ }^{7-15}$ Households enrolled in WIC purchased more whole-grain breads and brown rice. ${ }^{7}$ Retail scanner data demonstrated that WIC households also decreased purchases of juice. ${ }^{8}$ Native-American children participating in WIC reported increased consumption of whole-wheat bread at rates of four to seven times per week and two or more times per day and decreased consumption of white bread in an interview setting. ${ }^{9}$

Significant changes were observed in dietary intake in another study, with increased fruit consumption by 0.33 servings (one fruit serving is equivalent to 1 medium fruit, whereas $1 / 4$ cup dried fruit is equivalent to $1 / 2$ cup fresh, frozen, or canned fruit based on the 2005 Dietary Guidelines for Americans [DGA]) per day among Hispanic mothers enrolled in WIC. ${ }^{10}$ In the same study, low-fat dairy intake increased by 0.21 servings (one milk serving is equivalent to 1 cup milk, 1 cup yogurt, and 1.5-oz cheese based on the 2005 DGA) per day among Hispanic WIC-enrolled mothers, 0.34 servings per day among Hispanic WIC-enrolled children, and 0.24 servings per day for African-American WIC-enrolled children. $^{10}$ Native-American WIC-enrolled children consuming $\mathrm{F} / \mathrm{V}$ four or more times per day increased from $7.0 \%$ and $3.9 \%$, respectively, to $11.5 \%$ and $8.0 \%$ after the 2009 WIC food package revisions. ${ }^{9}$ Saturated fat intake decreased as the purchase of milk and cheese declined by $85 \mathrm{~g} / \mathrm{month}$ 


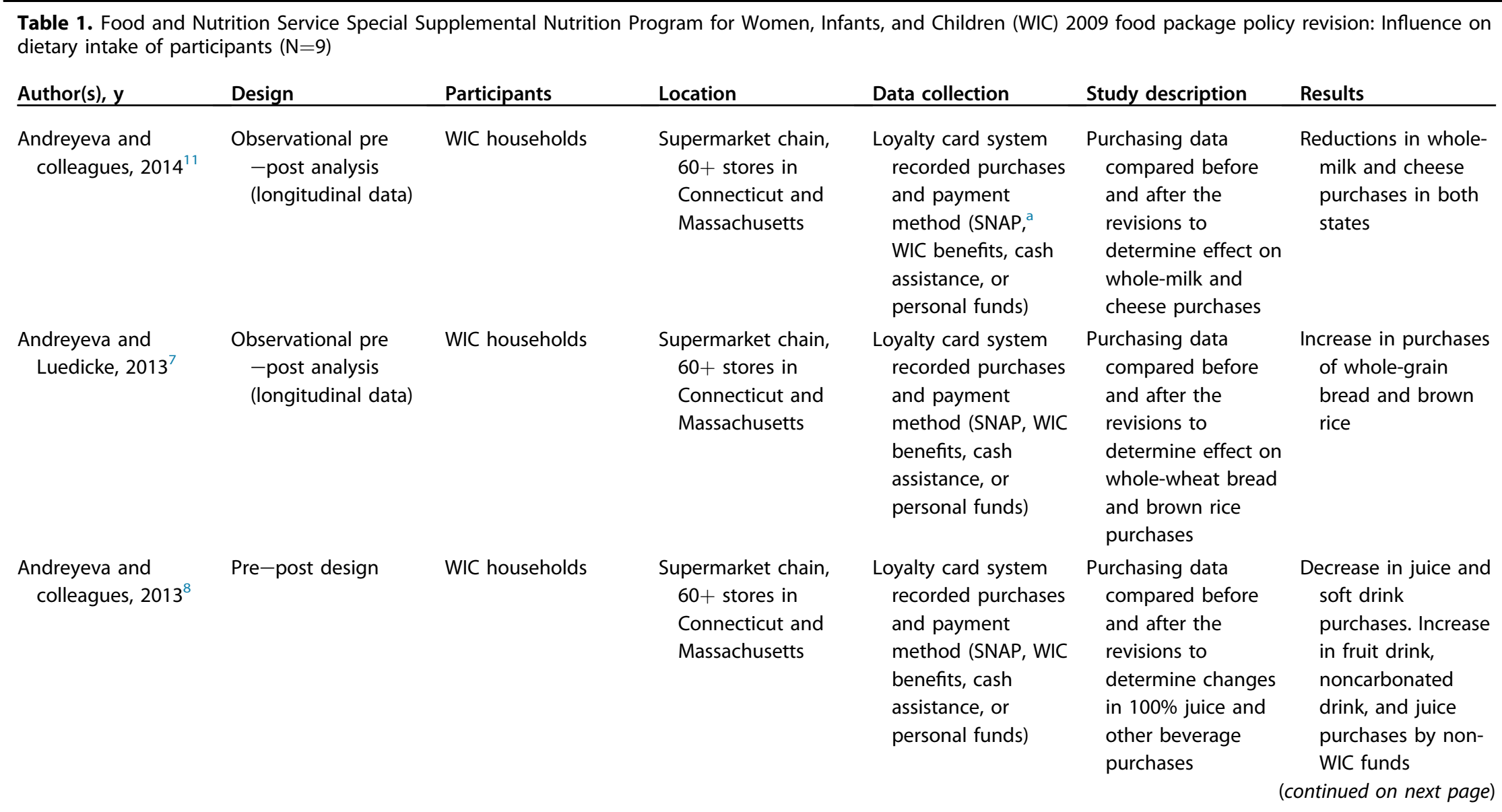


Table 1. Food and Nutrition Service Special Supplemental Nutrition Program for Women, Infants, and Children (WIC) 2009 food package policy revision: Influence on dietary intake of participants $(\mathrm{N}=9)$ (continued)

\begin{tabular}{|c|c|c|c|c|c|c|}
\hline Author(s), y & Design & Participants & Location & Data collection & Study description & Results \\
\hline $\begin{array}{l}\text { Black and colleagues, } \\
2009^{14}\end{array}$ & $\begin{array}{l}\text { Cross-sectional study, } \\
\text { qualitative }\end{array}$ & $\begin{array}{l}\text { WIC participants, } \\
\text { pregnant, or } \\
\text { primary caregiver to } \\
\text { WIC-enrolled child }\end{array}$ & $\begin{array}{l}\text { WIC clinics }(n=7) \text { in } \\
\text { diverse counties in } \\
\text { Maryland }\end{array}$ & $\begin{array}{l}\text { Interviews and focus } \\
\text { groups, adapted } \\
\text { food frequency } \\
\text { questionnaire, and } \\
\text { cost analysis }\end{array}$ & $\begin{array}{l}\text { Examined responses } \\
\text { to food package } \\
\text { changes, racial/ } \\
\text { ethnic differences, } \\
\text { and cost of } \\
\text { products }\end{array}$ & $\begin{array}{l}\text { Frequently consumed } \\
\text { are fruits and } \\
\text { vegetables and } \\
\text { commercial baby } \\
\text { foods. Consumption } \\
\text { of vegetables did } \\
\text { not differ among } \\
\text { ethnicities and } \\
\text { preference of form } \\
\text { (fresh, frozen, } \\
\text { canned) did. White } \\
\text { bread and non- } \\
\text { low-fat options } \\
\text { preferred. }\end{array}$ \\
\hline $\begin{array}{l}\text { Chiasson and } \\
\text { colleagues, } 2013^{13}\end{array}$ & Cross-sectional study & $\begin{array}{l}\text { WIC-enrolled infants } \\
\text { and children (aged } \\
0-4 \text { y) }\end{array}$ & New York & $\begin{array}{l}3.5 \text { million }+ \text { WIC } \\
\text { administrative } \\
\text { records (Statewide } \\
\text { Information } \\
\text { System) and parent } \\
\text { certification } \\
\text { interviews }\end{array}$ & $\begin{array}{l}\text { Examined WIC } \\
\text { revision influence } \\
\text { on nutrition-related } \\
\text { behavior and } \\
\text { obesity }\end{array}$ & $\begin{array}{l}\text { Delayed introduction } \\
\text { of solid foods and } \\
\text { daily fruit and } \\
\text { vegetable and } \\
\text { whole-grain intake. } \\
\text { Low nonfat milk } \\
\text { consumption by } \\
\text { children (aged 2-4 } \\
\text { y). Weight } \\
\text { reductions. }\end{array}$ \\
\hline $\begin{array}{l}\text { Ishdorj and Capps, } \\
\qquad 2013^{9}\end{array}$ & $\begin{array}{l}\text { Cross-sectional, pre } \\
\text {-post design }\end{array}$ & $\begin{array}{l}\text { Native-American WIC- } \\
\text { enrolled children } \\
\text { (aged } 2-4 \text { y) }\end{array}$ & $\begin{array}{l}\text { States in United States } \\
\quad(\mathrm{n}=40)\end{array}$ & $\begin{array}{l}\text { National Food and } \\
\text { Nutrition Survey for } \\
\text { WIC responses from } \\
\text { caregivers of } \\
\text { preschool-aged } \\
\text { children }\end{array}$ & $\begin{array}{l}\text { Consumption patterns } \\
\text { including milk, } \\
\text { fruits and } \\
\text { vegetables, and } \\
\text { grains }\end{array}$ & $\begin{array}{l}\text { Increased } \\
\text { consumption of } \\
\text { fruits and } \\
\text { vegetables, whole } \\
\text { grains, and low-fat } \\
\text { or fat-free milk } \\
\text { (continued on next page) }\end{array}$ \\
\hline
\end{tabular}


Table 1. Food and Nutrition Service Special Supplemental Nutrition Program for Women, Infants, and Children (WIC) 2009 food package policy revision: Influence on dietary intake of participants $(\mathrm{N}=9)$ (continued)

\begin{tabular}{|c|c|c|c|c|c|c|}
\hline Author(s), y & Design & Participants & Location & Data collection & Study description & Results \\
\hline $\begin{array}{l}\text { Kim and colleagues, } \\
2013^{15}\end{array}$ & $\begin{array}{l}\text { Cross-sectional, pre } \\
\text {-post design }\end{array}$ & $\begin{array}{l}\text { California WIC dyads } \\
\text { with infants (aged } \\
6-11 \mathrm{mo} \text { ) }\end{array}$ & California & $\begin{array}{l}\text { California Nutrition } \\
\text { Education \& Food } \\
\text { Package Impact } \\
\text { Survey and } \\
\text { California WIC } \\
\text { voucher } \\
\text { redemption } \\
\text { information }\end{array}$ & $\begin{array}{l}\text { Determined use and } \\
\text { satisfaction of } \mathrm{JBF}^{\mathrm{b}} \\
\text { and preferences for } \\
\text { cash value vouchers } \\
\text { for fruits and } \\
\text { vegetables in } \\
\text { comparison to JBF }\end{array}$ & $\begin{array}{l}\text { Decrease in JBF } \\
\text { consumption with } \\
\text { age among all } \\
\text { ethnic groups. } \\
\text { Preference to } \\
\text { receive additional } \\
\text { cash value vouchers } \\
\text { for fruits and } \\
\text { vegetables in place } \\
\text { of JBF. }\end{array}$ \\
\hline $\begin{array}{l}\text { Odoms-Young and } \\
\text { colleagues, } 2013^{10}\end{array}$ & Natural experiment & $\begin{array}{l}\text { Hispanic and African- } \\
\text { American WIC } \\
\text { dyads with children } \\
\text { (aged 2-3 y) }\end{array}$ & $\begin{array}{l}\text { WIC clinics }(\mathrm{n}=12) \text { in } \\
\text { Chicago, IL }\end{array}$ & $\begin{array}{l}\text { Cross-sectional survey } \\
\text { provided baseline } \\
\text { data for natural } \\
\text { experiment }\end{array}$ & $\begin{array}{l}\text { Postrevision influence } \\
\text { on home food } \\
\text { availability and } \\
\text { dietary change }\end{array}$ & $\begin{array}{l}\text { Variations by ethnic } \\
\text { group and no } \\
\text { significant } \\
\text { correlates between } \\
\text { home food } \\
\text { availability and } \\
\text { dietary change. } \\
\text { Increased home } \\
\text { food availability of } \\
\text { low-fat dairy and } \\
\text { whole grains. } \\
\text { Hispanic dyads and } \\
\text { African-American } \\
\text { children increased } \\
\text { low-fat dairy intake. } \\
\text { Hispanic mothers } \\
\text { increased fruit } \\
\text { intake. } \\
\text { (continued on next page) }\end{array}$ \\
\hline
\end{tabular}


per WIC household in Connecticut and $107 \mathrm{~g} / \mathrm{mo}$ in Massachusetts. ${ }^{11}$ Another study observed an increase in caregiver and child consumption of whole grains and fruits and a decrease of whole milk and fruit juice. ${ }^{12}$ In addition, a study assessing the New York State WIC program demonstrated that daily consumption of fruit, vegetables, and whole grains increased for WIC-enrolled children aged 1 to 4 years. ${ }^{13}$ Similarly, rates for $\geq 95$ th percentile weight-for-recumbent length among 1-year-old WIC-enrolled children and body mass index $\geq 95$ th percentile among 2- to 4-year-old WICenrolled children decreased after the revised WIC food packages were implemented. ${ }^{13}$

WIC participants who were interviewed supported the 2009 WIC food package revisions, specifically with regard to fruits, vegetables, and whole-grain products. On the other hand, the same WIC participants did not enjoy the reducedfat milk and soy product options. ${ }^{14}$ In addition, caregivers enjoyed the addition of jarred $\mathrm{F} / \mathrm{V}$ to the food package for infants aged 6 to 11 months, but many caregivers also wanted the option to choose between jarred foods and fresh F/V ${ }^{15}$ Results for dietary intake are compiled in Table 1.

\section{Availability of Healthy Foods and Beverages}

Managers and owners of WIC-authorized and non-WICauthorized vendors had mixed perceptions about consumer demand (eg, number of customers, sales, and profits) for healthy products and impressions of the 2009 WIC food package changes. ${ }^{16-18}$ WIC-authorized and non-WIC-authorized vendors at 58 non-supermarket retailers in five towns in Connecticut perceived lower customer demand for healthy food and beverage items compared with unhealthy foods and beverages after the 2009 WIC changes. ${ }^{16}$ Another study found that WIC-authorized retail storeowners' and managers' attitudes toward offering healthy foods positively increased after the revisions. ${ }^{17}$ These attitudes, collected through interview methodology, differed in non-WIC store managers; however, these changes were not statistically significant. ${ }^{17}$ Many retailers had a positive (46\%) or neutral (36\%) overall impression of the 2009 WIC food package revisions, compared with $18 \%$ who had a negative overall impression of consumer demand. ${ }^{16}$

Four studies demonstrated that WIC-authorized vendors improved healthy food and beverage availability compared with non-WIC vendors as a result of WIC food package revisions. $^{18-21}$ WIC-authorized vendors demonstrated the greatest benefit, showing an increase in sales of the emphasized food products ${ }^{17,22}$ and improved stocking of brown rice, fruits, ${ }^{23}$ whole-grain breads, and low-fat dairy options, but no significant change in fresh vegetables compared with nonWIC vendors. ${ }^{21}$ Furthermore, the WIC food package revisions influenced food prices, with modest reductions in price for canned $\mathrm{F} / \mathrm{V}$ at small stores in seven Illinois counties. ${ }^{18}$ Price reduction for $\mathrm{F} / \mathrm{V}$ did depend on the store size and location. Results for health food and beverage availability are compiled in Table 2.

\section{Breastfeeding Outcomes}

The 2009 WIC food package revisions had mixed results about breastfeeding initiation and duration. ${ }^{13,22-25}$ After the 2009 WIC food package revisions, the partial breastfeeding package issuance decreased, the full breastfeeding package 

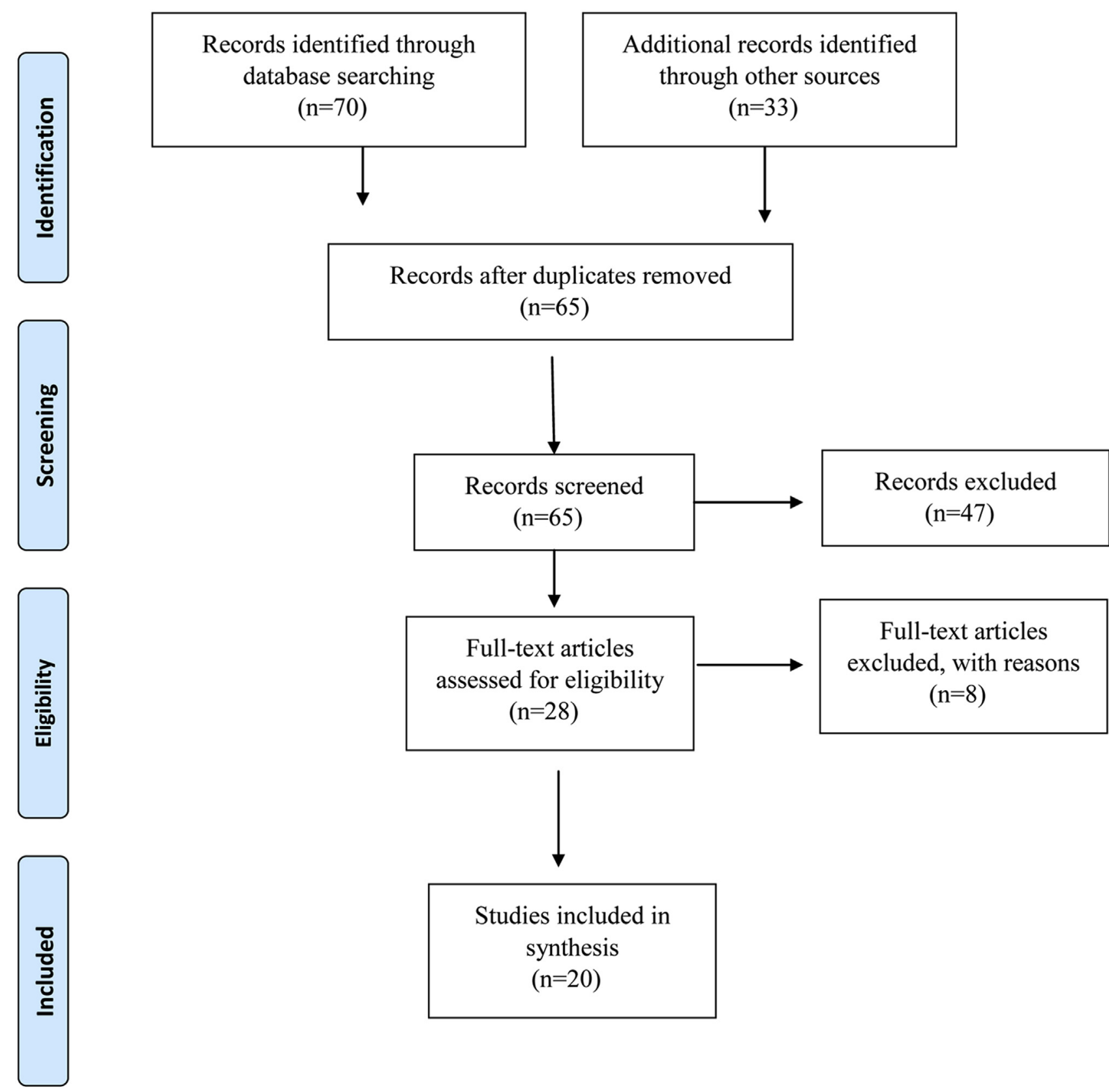

Figure. Preferred Reporting Items for Systematic Reviews and Meta-Analyses 2009 flow diagram. Terms used in this search included a combination of the following words: WIC; The Special Supplemental Nutrition Program for Women, Infants, and Children; food package; 2009; and revisions. Inclusion criteria for manuscripts were peer-reviewed, English language, and United States.

issuance increased, and the full formula package increased for mother-and-infant dyads during the birth month. ${ }^{24}$ The full breastfeeding package issuance did not change for dyads with infants aged 3 to 5 months. After the 2009 WIC food revisions, breastfeeding initiation rates were stable even with the changed assignments in the food packages ${ }^{24}$ (see Table 3).

Another study showed an $86 \%$ increased issuance rate of the full breastfeeding package and a 10\% decrease in issuance rates for formula-only packages after revisions. ${ }^{25} \mathrm{Ac}-$ cording to the study, training and education policies before the implementation of 2009 WIC food package revisions increased breastfeeding package issuance, decreased partial breastfeeding package issuance, and decreased formula package issuance. ${ }^{25} \mathrm{~A}$ study looking at WIC participants in Los Angeles county demonstrated an $8 \%$ increase in WIC participants exclusively breastfeeding through 3 months after the revisions occurred. ${ }^{26}$ An increase of $9 \%$ of WIC participants exclusively breastfeeding through 6 months also occurred in this population. ${ }^{26}$ In contrast, the study demonstrated that overall the new food package appeared to have had little or no effect on overall breastfeeding at 
Table 2. Food and Nutrition Service Special Supplemental Nutrition Program for Women, Infants, and Children (WIC) 2009 food package policy revision: Influence on healthy food and beverage availability (HFA) in both WIC and Non-WIC stores $(n=8)$

\begin{tabular}{|c|c|c|c|c|c|c|}
\hline Author(s), y & Design & Participants & Location & Data collection & Study description & Results \\
\hline $\begin{array}{l}\text { Andreyeva and } \\
\text { colleagues, } 2012^{20}\end{array}$ & Pre-post design & $\begin{array}{l}\text { Nonchain grocery } \\
\text { stores, both WIC- } \\
\text { certified }(n=33) \text { and } \\
\text { non-WIC }(n=229)\end{array}$ & $\begin{array}{c}\text { Towns }(n=5) \text { in } \\
\text { Connecticut }\end{array}$ & $\begin{array}{l}\text { Nutrition Environment } \\
\text { Measurement } \\
\text { Survey in stores }\end{array}$ & $\begin{array}{l}\text { Measured availability, } \\
\text { price, variety, and } \\
\text { quality of WIC- } \\
\text { approved foods and } \\
\text { before and after the } \\
\text { intervention, effect } \\
\text { on HFA }\end{array}$ & $\begin{array}{l}\text { WIC-certified stores } \\
\text { improved } \\
\text { availability and } \\
\text { variety of healthy } \\
\text { foods. } \\
\text { Non-WIC stores had } \\
\text { mild increase. }\end{array}$ \\
\hline $\begin{array}{l}\text { Andreyeva and } \\
\text { colleagues, } 2011^{17}\end{array}$ & Pre-post design & $\begin{array}{l}\text { Owners/managers of } \\
\text { WIC-certified and } \\
\text { non-WIC stores }\end{array}$ & $\begin{array}{l}\text { Nonsupermarket } \\
\text { retailers in } \\
\text { Connecticut towns } \\
(n=5)\end{array}$ & $\begin{array}{l}\text { In-person } \\
\text { standardized } \\
\text { interviews }\end{array}$ & $\begin{array}{l}\text { Perception of } \\
\text { demand, supply, } \\
\text { and barriers to } \\
\text { stocking healthy } \\
\text { foods }\end{array}$ & $\begin{array}{l}\text { Demand primary } \\
\text { factor in stocking } \\
\text { decisions with } \\
\text { weaker demand for } \\
\text { healthier food. } \\
\text { Some product } \\
\text { demands increased } \\
\text { after the revision. }\end{array}$ \\
\hline $\begin{array}{l}\text { Ayala and colleagues, } \\
2012^{16}\end{array}$ & Cross-sectional study & $\begin{array}{l}\text { Owners/managers } \\
\text { (1 y experience) of } \\
\text { small WIC-certified } \\
\text { stores }\end{array}$ & $\begin{array}{l}\text { Major cities }(\mathrm{n}=8) \text { in } \\
\text { Maryland, Illinois, } \\
\text { Minnesota, } \\
\text { Connecticut, } \\
\text { Louisiana, } \\
\text { Pennsylvania, and } \\
\text { California }\end{array}$ & $\begin{array}{l}\text { In-depth interviews } \\
\text { with open and } \\
\text { close-ended } \\
\text { questions }\end{array}$ & $\begin{array}{l}\text { Influence of WIC } \\
\text { revisions on } \\
\text { perceived sales, } \\
\text { product selection, } \\
\text { and stocking habits }\end{array}$ & $\begin{array}{l}\text { Consumer requests, } \\
\text { cold storage, and } \\
\text { profitability } \\
\text { important for } \\
\text { stocking decisions. } \\
\text { Perceived increase } \\
\text { in sales for most } \\
\text { products. No } \\
\text { change in sales for } \\
\text { processed fruits and } \\
\text { vegetables. }\end{array}$ \\
\hline $\begin{array}{l}\text { Gittelsohn and } \\
\text { colleagues, } 2012^{18}\end{array}$ & Qualitative study & $\begin{array}{l}\text { Owners/managers (1 } \\
\text { y experience) of } \\
\text { small WIC-certified } \\
\text { stores }\end{array}$ & $\begin{array}{l}\text { Major cities }(\mathrm{n}=8) \text { in } \\
\text { Maryland, Illinois, } \\
\text { Minnesota, } \\
\text { Connecticut, } \\
\text { Louisiana, } \\
\text { Pennsylvania, and } \\
\text { California }\end{array}$ & In-depth interviews & $\begin{array}{l}\text { Vendor perspectives } \\
\text { of WIC food } \\
\text { package revisions }\end{array}$ & $\begin{array}{l}\text { Reported increase in } \\
\text { customers, sales, } \\
\text { and profits. Steady } \\
\text { supply of perishable } \\
\text { foods and } \\
\text { explaining new } \\
\text { rules are challenges. } \\
\text { (continued on next page) }\end{array}$ \\
\hline
\end{tabular}


Table 2. Food and Nutrition Service Special Supplemental Nutrition Program for Women, Infants, and Children (WIC) 2009 food package policy revision: Influence on healthy food and beverage availability (HFA) in both WIC and Non-WIC stores $(n=8)$ (continued)

\begin{tabular}{|c|c|c|c|c|c|c|}
\hline Author(s), y & Design & Participants & Location & Data collection & Study description & Results \\
\hline $\begin{array}{l}\text { Havens and } \\
\text { colleagues, } 2012^{22}\end{array}$ & Pre-post design & Corner stores $(n=45)$ & Hartford, CT & $\begin{array}{l}\text { Store inventories with } \\
\text { use of revised } \\
\text { Nutrition } \\
\text { Environment } \\
\text { Measurement } \\
\text { Survey in stores }\end{array}$ & $\begin{array}{l}\text { Availability of fresh } \\
\text { fruits and } \\
\text { vegetables, whole } \\
\text { grains, and low-fat } \\
\text { milk in WIC-certified } \\
\text { stores in } \\
\text { comparison to non- } \\
\text { WIC stores }\end{array}$ & $\begin{array}{l}\text { Increased availability } \\
\text { of produce, whole- } \\
\text { grain foods, and } \\
\text { lower-fat milk in } \\
\text { WIC-certified stores }\end{array}$ \\
\hline $\begin{array}{l}\text { Hillier and colleagues, } \\
2012^{21}\end{array}$ & Pre-post design & $\begin{array}{l}\text { Supermarket, grocery } \\
\text { stores, and } \\
\text { nonchain corner } \\
\text { stores }(n=141)\end{array}$ & Philadelphia, PA & $\begin{array}{l}\text { Stores identified } \\
\text { through field } \\
\text { enumeration and } \\
\text { surveyed using } \\
\text { Nutrition } \\
\text { Environment } \\
\text { Measurement } \\
\text { Survey in stores }\end{array}$ & $\begin{array}{l}\text { Influence of WIC food } \\
\text { package revisions } \\
\text { on HFA in } 2 \text { low- } \\
\text { income areas }\end{array}$ & $\begin{array}{l}\text { Increase in HFA } \\
\text { postpolicy change } \\
\text { overall with } \\
\text { substantial } \\
\text { increases in WIC- } \\
\text { certified stores }\end{array}$ \\
\hline $\begin{array}{l}\text { Zenk and colleagues, } \\
2012^{19}\end{array}$ & $\begin{array}{l}\text { Quasiexperimental, } \\
\text { 1-group, pre-post } \\
\text { design }\end{array}$ & WIC-certified vendors & $\begin{array}{l}\text { Northern Illinois } \\
\text { counties }(n=7) \text { not } \\
\text { inclusive of Chicago }\end{array}$ & $\begin{array}{l}\text { Trained observers } \\
\text { assessed fresh, } \\
\text { frozen, and canned } \\
\text { fruits and } \\
\text { vegetables using } \\
\text { adapted instrument }\end{array}$ & $\begin{array}{l}\text { Examined availability } \\
\text { and selection of } \\
\text { common and } \\
\text { culturally specific } \\
\text { fruit and vegetable } \\
\text { availability }\end{array}$ & $\begin{array}{l}\text { Improved selection of } \\
\text { common fresh fruits } \\
\text { and vegetables and } \\
\text { availability to } \\
\text { African-American } \\
\text { culturally specific } \\
\text { fresh fruits and } \\
\text { vegetables. Mildly } \\
\text { improved } \\
\text { availability of } \\
\text { canned (low- } \\
\text { sodium) vegetables } \\
\text { and frozen fruits } \\
\text { and vegetables. } \\
\text { Data differed by } \\
\text { vendor, not } \\
\text { neighborhood } \\
\text { characteristics. } \\
\text { (continued on next page) }\end{array}$ \\
\hline
\end{tabular}


Table 2. Food and Nutrition Service Special Supplemental Nutrition Program for Women, Infants, and Children (WIC) 2009 food package policy revision: Influence on healthy food and beverage availability (HFA) in both WIC and Non-WIC stores $(n=8)$ (continued)

Author(s), y

Zenk and colleagues, $2014^{23}$

$$
\text { Design }
$$

Quasiexperimental pre-post design

\section{Participants}

WIC-certified vendors

\section{Data collection}

WIC Northern Illinois Vendor Project

instrument

adaptation

\section{Study description}

Determined

availability and

price of fruits and

vegetables with

vendor

characteristics

\section{Results}

Higher canned and frozen fruits and vegetables prices and lower fresh fruits and vegetables prices among small vendors. Lower canned and frozen fruits and vegetables prices and higher fresh prices among large vendors.

Differences

dependent on type and neighborhood

of vendor. 
Table 3. Food and Nutrition Service Special Supplemental Nutrition Program for Women, Infants, and Children (WIC) 2009 food package policy revision: Influence on breastfeeding (BF) initiation and duration and issuance of BF packages $(n=3)$

\begin{tabular}{|c|c|c|c|c|c|c|}
\hline Author(s), y & Design & Participants & Location & Data collection & Study description & Results \\
\hline $\begin{array}{l}\text { Langellier and } \\
\text { colleagues, } \\
2014^{26}\end{array}$ & $\begin{array}{l}\text { Repeated cross- } \\
\text { sectional study }\end{array}$ & $\begin{array}{l}\text { WIC participants, } \\
\text { Latina (majority) }\end{array}$ & $\begin{array}{l}\text { Los Angeles County, } \\
\text { CA }\end{array}$ & $\begin{array}{l}\text { Survey adapted from } \\
\text { Los Angeles County } \\
\text { Health Survey with } \\
\text { input from } \\
\text { California State WIC } \\
\text { Division and WIC } \\
\text { local agency staff }\end{array}$ & $\begin{array}{l}\text { Demonstrates effect } \\
\text { of WIC revisions on } \\
\text { BF initiation and } \\
\text { duration }\end{array}$ & $\begin{array}{l}\text { Increase in BF } \\
\text { initiation with } \\
\text { significant increase } \\
\text { at } 3 \text { and } 6 \text { mo }\end{array}$ \\
\hline $\begin{array}{l}\text { Whaley and } \\
\text { colleagues, } \\
2012^{25}\end{array}$ & Pre-post design & WIC infants & Southern California & $\begin{array}{l}\text { WIC administrative } \\
\text { data }\end{array}$ & $\begin{array}{l}\text { Prerevision } \\
\text { participant } \\
\text { education focused } \\
\text { on package } \\
\text { changes, BF } \\
\text { incentives, and } \\
\text { importance of } \\
\text { making BF decision } \\
\text { early on }\end{array}$ & $\begin{array}{l}\text { Full BF package } \\
\text { increased } \\
\text { postrevision (86\%) }\end{array}$ \\
\hline $\begin{array}{l}\text { Wilde and } \\
\text { colleagues, } \\
2012^{24}\end{array}$ & Pre-post design & $\begin{array}{l}\text { WIC-enrolled dyads } \\
\text { with infant (aged 0- } \\
5 \mathrm{mo} \text { ) }\end{array}$ & $\begin{array}{l}\text { California, Florida, } \\
\text { Georgia, Idaho, } \\
\text { Illinois, Minnesota, } \\
\text { Rhode Island, } \\
\text { Tennessee, Texas, } \\
\text { and Utah }\end{array}$ & $\begin{array}{l}\text { Administrative } \\
\text { records for local } \\
\text { WIC agencies }\end{array}$ & $\begin{array}{l}\text { Assessed changes in } \\
\text { WIC food-package } \\
\text { assignments, infant } \\
\text { formula, and BF } \\
\text { initiation }\end{array}$ & $\begin{array}{l}\text { Increased issuance of } \\
\text { both full BF } \\
\text { packages and full } \\
\text { formula packages. } \\
\text { No change in BF } \\
\text { initiation rates. }\end{array}$ \\
\hline
\end{tabular}


3 and 6 months, after adjustment for other factors. ${ }^{26}$ In addition, a study that looked at various influences of the food pack revisions demonstrated a $7.3 \%$ increase in breastfeeding initiation ${ }^{13}$ (see Table 3).

\section{DISCUSSION}

The 2009 WIC food revisions demonstrated a positive influence on WIC participants' dietary intake. Increased consumption of fruits, vegetables, and whole-grain products were prevalent after the revisions. WIC participants bought less juice, white bread, and whole milk postimplementation. Overall, improvement in whole-grain consumption was widely established in the research.

Although studies demonstrated improved F/V consumption, this improvement was minimal. Future research should assess why the improved F/V consumption was limited. Potential studies could focus on assessing higher cash value voucher allotments for acquiring produce. Furthermore, research could focus on the required WIC educational lessons and how to integrate education on preparing and purchasing fresh, frozen, dried, or canned produce.

In February 2015, an expert IOM committee published the first of three reports on the WIC food packages. ${ }^{27}$ The first report addressed the topic of white potatoes being ineligible for purchase with the WIC cash value voucher. ${ }^{27}$ The committee recommended that white potatoes contain similar nutritional properties of other starchy vegetables that are currently permitted for purchase with the cash value voucher. ${ }^{27}$ The committee found no direct evidence to support that consumption of white potatoes adversely affected the health outcomes for WIC participants. ${ }^{27}$ The committee decided to allow white potatoes to henceforth be a WIC-eligible vegetable in the cash value voucher. Future research should assess whether the allowance of white potatoes increases vegetable intake with WIC participants and whether this cash value voucher white potato eligibility displaces consumption of other vegetable sources.

Despite the minimal produce consumption change, improvement in dietary intake among WIC participants from the 2009 revisions are closer to meeting the 2010 DGA. $^{28}$ Specific improvements that are particularly important involve helping WIC participants reduce consumption of sugar and solid fats and increase consumption of whole grains, low-fat dairy, and fruits. ${ }^{28}$ WIC can also continue to limit juice allotments to help reduce higher consumption rates among WIC participants. ${ }^{29}$ With the recent publication of the 2015 DGA, future research should assess whether the food packages meet these new recommendations. Similarly, WIC could be modified to meet the DGA recommendations through the upcoming 2015 Child Nutrition Reauthorization Act.

As the revisions become more established, future research should analyze long-term effects of 2009 WIC food package revisions. For example, robust anthropometric measurements, such as body mass index, could be assessed with WIC participants. Future research should assess the specific use of specific food package products through multiple pass dietary recalls. Additional qualitative interviews should be conducted with participants about food package products are incorporated into the diet, such as brown rice, beans, and vegetables.

The 2009 WIC food package revisions have demonstrated that USDA policy can improve dietary intake for consumers and healthy food and beverage availability in the retail environment. Researchers, practitioners, and policy have suggested improving the nutritional quality of foods allowed in other federal food and nutrition assistance programs, such as the Supplemental Nutrition Assistance Program (SNAP), also operated by the USDA. ${ }^{30}$ Whereas the WIC program serves a large population of infants and children, $48 \%$ of SNAP participants are children and SNAP encompasses three times more children than WIC. ${ }^{31}$ Due to this large reach, SNAP could test the influence of setting nutrition guidelines similar to other supplemental feeding programs such as WIC, National School Lunch Program, and USDA's Child and Adult Care Food Program. In addition, the 2015 Dietary Guidelines Advisory Committee supported aligning food assistance programs such as SNAP and WIC with their recommendations. ${ }^{32}$ Like WIC's vendor stocking requirements, research has shown that more than $58 \%$ of key stakeholders interviewed in regard to nutritionrelated changes to SNAP recommended SNAP retailers should stock a minimum quantity of healthful foods. ${ }^{30}$ Participants enrolled in SNAP have also demonstrated support for incentives to encourage $F / V$ consumption and limitations to decrease consumption of sugar-sweetened beverages. ${ }^{33}$ Currently, SNAP is not supporting participants in meeting the 2010 DGA. ${ }^{34}$ The positive WIC revisions of improved dietary intake, limiting consumption of unhealthy products, and improved healthy food and beverage availability could also provide positive changes to SNAP. $^{30}$

The 2009 WIC food package revisions were associated with improved healthy food and beverage accessibility, although limitations still existed. Overall, availability of $\mathrm{F} / \mathrm{V}$ increased in 7 northern Illinois counties after the revision. ${ }^{18}$ WIC vendors' inventories carried more varieties of fruit and increased the availability of whole grains and low-fat milk. To a lesser degree, the revisions affected non-WIC vendors, who also increased their availability of healthy food. ${ }^{16}$ Further analysis should be completed to identify why stores do not participate in WIC and strategies to address any challenges. Future studies should assess the quality and diversity of foods offered by WIC vendors. In addition, purchasing data could be used to assess what $\mathrm{F} / \mathrm{V}$ are being purchased with cash value vouchers. These inventory questions should be evaluated to understand issues in product sourcing and consumer demand.

The mission of increasing breastfeeding participation with the 2009 WIC food package revisions had mixed results. Whaley and colleagues ${ }^{25}$ demonstrated a decline in issuance of partial breastfeeding packages and an increase in full breastfeeding and formula packages. In total, three studies have been published to date on breastfeeding participation after the 2009 WIC food package changes. Further research should assess strategies to increase breastfeeding participation (ie, both initiation and duration).

Despite WIC's overwhelming support for breastfeeding mothers, the breastfeeding rate of WIC participants is $20 \%$ lower than non-WIC participants. ${ }^{35}$ Currently, non-WIC 
participants are 2.11 times more likely to breastfeed than WIC participants, up from 1.4 times more likely in $1984 .{ }^{36}$ Researchers have argued that WIC should address its financial support of formula. ${ }^{37}$ In 2009 , \$34 million or $0.6 \%$ of the total WIC budget was designated for breastfeeding initiatives. ${ }^{35}$ In contrast, formula accounted for $\$ 850$ million (11.6\%) of WIC's fiscal year 2009 expenses. ${ }^{37}$ WIC incurs cost savings from rebates from formula manufacturers in exchange for their business and are legally required to bid for contracts with formula makers. ${ }^{37}$ Notably, rebates from formula companies support WIC's ability to serve more clients. ${ }^{37}$

Some researchers have suggested shifting funding from formulas to peer counseling programs that support breastfeeding. ${ }^{37}$ Studies have shown that WIC participants who use peer counseling programs have experienced higher breastfeeding rates. ${ }^{38}$ Furthermore, a common reason for the low use of peer-counseling programs among WIC programs is lack of financial support. ${ }^{38}$ Ongoing research is needed about the influence of WIC's formula rebate system on breastfeeding initiation and duration.

Despite the criticism of WIC's financial support of formula, social barriers stand in the way of participants' breastfeeding participation rates as well. ${ }^{37}$ Positive support systems from partners, family, and the workplace are important for breastfeeding initiation and duration, which may be lacking among some populations of low-income women. ${ }^{39}$ One study shows that incentivizing baby items like bottles, baby bibs/ clothes, car seats, strollers, and diapers encourages women to stop smoking. ${ }^{40}$ Incentive programs should be researched to assess their influence on exclusive breastfeeding in the WIC program.

There were several limitations to the methods used for completing the systematic review. The limited search terms used in the literature review may not have retrieved all articles relevant to the 2009 WIC food package revisions. As such, any conclusions made in the review may not describe the breadth of all published work on this topic. Excluding non-peer-reviewed research may have discounted important work addressing WIC, such as theses, USDA Economic Research Survey reports, or dissertations. This limitation is warranted because the 2015 DGA, ${ }^{28}$ which guide the WIC food package contents, use a peer-review approach in the development of nutrition guidelines. In addition, relatively few studies were abstracted for our review and, as such, further studies are needed to provide conclusive evidence about dietary intake, availability of healthy food and beverages, and breastfeeding participation before and after the 2009 WIC food package revisions.

\section{CONCLUSIONS}

Overall, the 2009 WIC food package revisions helped improve healthy food and beverage availability and dietary intake among participants. The USDA should continue to pursue having WIC food packages match the DGA recommendations. Improving the nutritional quality of the WIC food packages is an important measure in helping to curb diet-related diseases in women, infants, and children.

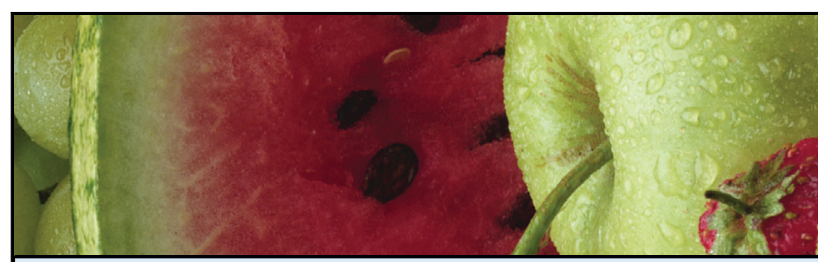

\section{PRACTICE IMPLICATIONS}

Although evidence exists about dietary intake, stocking inventories, and breastfeeding participation of the 2009 WIC food package revisions, no comprehensive review has been completed. Currently, no one has summarized multiple studies on the changes to the 2009 food packages and assessed its overall influence. Findings from this review can inform policy makers, researchers, and food and nutrition practitioners on the influence the 2009 food package revisions had on WIC participants and vendors. These discoveries can help provide feedback about what has worked in terms of reconfiguring the package and where the gaps exist for future improvements. Information from this review can also further enhance WIC's Competent Professional Authority personnel. These results can help strengthen the educational lessons from WIC personnel to improve efficacy of the food products promoted in the 2009 revisions that are not being increased currently in participants' diets.

Furthermore, the dietary intake and food access improvement from 2009 WIC food package revisions have demonstrated that USDA policy can change our food environment and individual intake. As food and nutrition practitioners look to improve dietary intake across different demographic groups, reconfiguring food assistance policy to support health, not just caloric intake, should be considered as part of our solutions.

\section{References}

1. Oliveira VJ. WIC Program: Background, Trends, and Economic Issues Darby, PA: DIANE Publishing; 2009.

2. National Research Council. WIC Food Packages: Time for a Change. Washington, DC: The National Academies Press; 2005.

3. US Department of Agriculture Food and Nutrition Service. Special Supplemental Nutrition Program for Women, Infants and Children (WIC): Revisions in the WIC Food Packages; Interim Rule. Washington, DC: US Government Printing Office; 2007.

4. US Department of Agriculture Food and Nutrition Service. Special Supplemental Nutrition Program for Women, Infants and Children (WIC) Revisions in the WIC Food Packages Rule To Increase Cash Value Vouchers for Women. Washington, DC: US Government Printing Office; 2009.

5. US Department of Agriculture Food and Nutrition Service. Special Supplemental Nutrition Program for Women, Infants and Children (WIC): Revisions in the WIC Food Packages; Final Rule. Washington, DC: US Government Printing Office; 2014.

6. Moher D, Liberati A, Tetzlaff J, Altman DG; The PRISMA group Preferred Reporting Items For Systematic Reviews And MetaAnalyses: The PRISMA statement. PLoS Med. 2009;6(7):e1000097.

7. Andreyeva T, Luedicke J. Federal food package revisions effects on purchases of whole-grain products. Am J Prev Med. 2013;45(4): 422-429.

8. Andreyeva T, Luedicke J, Tripp AS, Henderson KE. Effects of reduced juice allowances in food packages for the Women, Infants, and Children program. Pediatrics. 2013;131(5):919-927.

9. Ishdorj $\mathrm{A}$, Capps $\mathrm{O}$. The effect of revised WIC food packages on Native American children. Am J Agric Econ. 2013;95(5):1266-1272. 
10. Odoms-Young AM, Kong A, Schiffer LA, et al. Evaluating the initial impact of the revised Special Supplemental Nutrition Program for Women, Infants, and Children (WIC) food packages on dietary intake and home food availability in African-American and Hispanic families. Public Health Nutr. 2014;17(01):83-93.

11. Andreyeva T, Luedicke J, Henderson KE, Schwartz MB. The positive effects of the revised milk and cheese allowances in the Special Supplemental Nutrition Program for Women, Infants, and Children. J Acad Nutr Diet. 2014;114(4):622-630.

12. Whaley SE, Ritchie LD, Spector P, Gomez J. Revised WIC food package improves diets of WIC families. J Nutr Educ Behav. 2012;44(3):204209.

13. Chiasson MA, Findley SE, Sekhobo JP, et al. Changing WIC changes what children eat. Obesity. 2013;21(7):1423-1429.

14. Black MM, Hurley KM, Oberlander SE, et al. Participants' comments on changes in the revised Special Supplemental Nutrition Program for Women, Infants, and Children food packages: The Maryland food preference study. J Am Diet Assoc. 2009;109(1):116-123.

15. Kim LP, Whaley SE, Gradziel PH, Crocker NJ, Ritchie LD, Harrison GG. Mothers prefer fresh fruits and vegetables over jarred baby fruits and vegetables in the new Special Supplemental Nutrition Program for Women, Infants, and Children food package. J Nutr Educ Behav. 2013;45(6):723-727.

16. Andreyeva T, Middleton AE, Long MW, Luedicke J, Schwartz MB Food retailer practices, attitudes and beliefs about the supply of healthy foods. Public Health Nutr. 2011;14(06):1024-1031.

17. Gittelsohn J, Laska MN, Andreyeva T, et al. Small retailer perspectives of the 2009 Women, Infants and Children Program food package changes. Am J Health Behav. 2012;36(5):655-665.

18. Zenk SN, Odoms-Young A, Powell LM, et al. Fruit and vegetable availability and selection Federal Food Package revisions, 2009. Am J Prev Med. 2012;43(4):423-428.

19. Andreyeva T, Luedicke J, Middleton AE, Long MW, Schwartz MB. Positive influence of the revised Special Supplemental Nutrition Program for Women, Infants, and Children food packages on access to healthy foods. J Acad Nutr Diet. 2012;112(6):850-858.

20. Hillier A, McLaughlin J, Cannuscio CC, Chilton M, Krasny S, Karpyn A. The impact of WIC food package changes on access to healthful food in 2 low-income urban neighborhoods. J Nutr Educ Behav. 2012;44(3):210-216.

21. Havens EK, Martin KS, Yan J, Dauser-Forrest D, Ferris AM. Federal Nutrition Program changes and healthy food availability. Am J Prev Med. 2012;43(4):419-422.

22. Ayala GX, Laska MN, Zenk SN, et al. Stocking characteristics and perceived increases in sales among small food store managers owners associated with the introduction of new food products approved by the Special Supplemental Nutrition Program for Women, Infants, and Children. Public Health Nutr. 2012;15(09):17711779.

23. Zenk SN, Powell LM, Odoms-Young AM, et al. Impact of the revised Special Supplemental Nutrition Program for Women, Infants, and Children (WIC) food package policy on fruit and vegetable prices. J Acad Nutr Diet. 2014;114(2):288-296.

24. Wilde P, Wolf A, Fernandes M, Collins A. Food-package assignments and breastfeeding initiation before and after a change in the Special Supplemental Nutrition Program for Women, Infants, and Children. Am J Clin Nutr. 2012;96(3):560-566.

25. Whaley SE, Koleilat M, Whaley M, Gomez J, Meehan K, Saluja K. Impact of policy changes on infant feeding decisions among low- income women participating in the Special Supplemental Nutrition Program for Women, Infants, and Children. Am J Public Health. 2012;102(12):2269-2273.

26. Langellier BA, Chaparro MP, Wang MC, Koleilat M, Whaley SE. The new food package and breastfeeding outcomes among Women, Infants, and Children participants in Los Angeles County. Am J Public Health. 2014;104(suppl 1):S112-S118.

27. National Research Council. Review of WIC food packages: An evaluation of white potatoes in the cash value voucher: Letter report. https://www.iom.edu:443/Reports/2015/Review-WIC-Food-PackagesLetter-Report.aspx. Published February 2015. Accessed March 8, 2015.

28. Nutrition and Your Health: Dietary Guidelines for Americans, 2010, 7th edition. Washington, DC: US Government Printing Office; 2010.

29. Watowicz RP, Taylor CA. A comparison of beverage intakes in US children based on WIC participation and eligibility. J Nutr Educ Behav. 2014;46(3 suppl):S59-S64.

30. Leung CW, Hoffnagle EE, Lindsay AC, et al. A qualitative study of diverse experts' views about barriers and strategies to improve the diets and health of Supplemental Nutrition Assistance Program (SNAP) beneficiaries. J Acad Nutr Diet. 2013;113(1):70-76.

31. Long MW, Leung CW, Cheung LW, Blumenthal SJ, Willett WC. Public support for policies to improve the nutritional impact of the Supplemental Nutrition Assistance Program (SNAP). Public Health Nutr. 2014;17(1):219-224.

32. US Department of Agriculture Food and Nutrition Service. Building a healthy America: A profile of the Supplemental Nutrition Assistance Program. http://www.fns.usda.gov/sites/default/files/ BuildingHealthyAmerica.pdf. Published April 2012. Accessed April 2014.

33. US Departments of Agriculture and Health and Human Services. Scientific report of the 2015 Dietary Guidelines Advisory Committee. http://health.gov/dietaryguidelines/2015-scientific-report/PDFs/ScientificReport-of-the-2015-Dietary-Guidelines-Advisory-Committee.pdf. Published February 2015. Accessed February 2015.

34. Hilmers A, Chen T-A, Dave JM, Thompson D, Cullen KW. Supplemental Nutrition Assistance Program participation did not help low income Hispanic women in Texas meet the dietary guidelines. Prev Med. 2014;62:44-48.

35. Lawrence RA. Lower breastfeeding rates among Supplemental Nutrition Program for Women, Infants, and Children participants: A call for action. Pediatrics. 2006;117(4):1432-1433.

36. Ryan AS, Zhou W. Lower breastfeeding rates persist among the Special Supplemental Nutrition Program for Women, Infants, and Children participants, 1978-2003. Pediatrics. 2006;117(4):11361146.

37. Baumgartel KL, Spatz DL. WIC (The Special Supplemental Nutrition Program for Women, Infants, and Children): Policy versus practice regarding breastfeeding. Nurs Outlook. 2013;61(6):466-470.

38. Gross SM, Resnik AK, Cross-Barnet C, Nanda JP, Augustyn M, Paige DM. The differential impact of WIC peer counseling programs on breastfeeding initiation across the state of Maryland. J Hum Lact. 2009;25(4):435-443.

39. Darfour-Oduro SA, Kim J. WIC mothers' social environment and postpartum health on breastfeeding initiation and duration. Breastfeed Med. 2014;9(10):524-529.

40. Crossland N, Thomson G, Morgan H, Dombrowski SU, Hoddinott P. Incentives for breastfeeding and for smoking cessation in pregnancy: An exploration of types and meanings. Soc Sci Med. 2015;128:10-17. 


\section{AUTHOR INFORMATION}

D. J. Schultz is project administrator, ChildObesity180, Tufts University, Boston, MA; at the time of the study, he was a graduate student and dietetic intern, Montana State University, Bozeman. C. Byker Shanks is an assistant professor of food and nutrition and sustainable food systems, and B. Houghtaling is a graduate student, instructor, and research assistant, Montana State University, Bozeman.

Address correspondence to: Daniel Joseph Schultz, MS, 74 Boylston St \#3, Jamaica Plain, MA 02130. E-mail: schudj25@gmail.com

\section{STATEMENT OF POTENTIAL CONFLICT OF INTEREST}

No potential conflict of interest was reported by the authors.

\section{FUNDING/SUPPORT}

None to report.

\section{ACKNOWLEDGEMENTS}

The authors thank Christopher Seitz, DrPH, for his contribution to the review. 